\title{
Continued Usage of Bike-Sharing Services: An Extended Expectation-Confirmation Model Analysis
}

\author{
Lianfeng Xu \\ School of Economics and Management \\ Minjiang University \\ Fuzhou, China
}

\begin{abstract}
Bike-sharing services follow the model of the sharing economy. The continued usage of these services exerts significant influence upon the shared-bike market. This research applies the expectation-confirmation model to the continued usage of shared-bike services. The model is extended based on the characteristics of bike-sharing services and the behaviour of their users. Additionally, structural equation modeling is applied to show the feasibility of the extended model. The results show that the use of bike-sharing services not only has a positive effect on the users' perceptions of the service in terms of its practicality, but also improves their levels of satisfaction. The perceived usefulness of the service and a high level of satisfaction of the shared-bike users are proportional to their intention to continue to use the bike-sharing service. Their trust in the bike-sharing service also affects their continued usage intention. The users' continued usage intention of bike-sharing services and their corresponding behaviour are affected by their habits of using this service, while their perceived pleasure exerts no significant effect upon their level of satisfaction and continued usage intention.
\end{abstract}

Keywords-shared-bike; continued usage behavior; expectation-confirmation model

\section{INTRODUCTION}

The shared-bikes model has developed from its original form of a means of transportation from the start point to the final destination (known as 'the last one kilometre') to regular campus cycling, short-distance cycling tours, and shopping, thus making the daily travelling of the public more convenient. Currently, shared-bikes can be seen everywhere in public space. The only thing users need to do before using them is to scan the QR code on the bikes with their mobile phones. They are rented hourly because of the consumption pattern of the people. Users can rent bikes according to their needs. The rapid development of bike-sharing services indicates that their commercial value and market potential are enormous. The consistent consumption of these services is an important index showing the value of the enterprises [1]. In light of the failure of several participating companies, it is the acceptance of users that determines the success of emerging companies.

Users are more willing to choose products that offer them high value. Knowing that people are in need of appropriate transportation for short-distance travel, bike-sharing companies aim to induce continued usage behaviour among their users. Currently, most of the research has focused on the development

Project Name: The Model Research of Targeted Financial Poverty Alleviation in The View of Agriculture Supply-side Structural Reform.

Subject Source: Inclusive Financial and Rural E-commerce Collaborative Innovation Center in Minjiang University.

Subject Number: XTZX1816 aspect of bike-sharing along with related social issues, ranging from the development of bike-sharing to the profitability of the industry [2]. Additionally, researchers have discussed the legal issues relevant to bike-sharing services, including the responsibility of bike-renting and the vandalisation of sharedbikes [3-4]. However, little research has been conducted regarding the actual use of these services. As the sharing economy continues to grow, the continued use of shared-bikes ultimately decides the future of the bike-sharing industry. This article discusses the use of bike-sharing services. The continued usage behaviour and the level of satisfaction of shared-bike users are analyzed through an expectationconfirmation model (ECM) that has been extended according to the characteristics of bike-sharing services.

\section{RESEARCH MODEL AND HYPOTHESIS}

\section{A. Continued usage and the ECM}

The ECM is based on ECM of Oliver [5] and the technology acceptance model of Davis [6]. Oliver believes that the reason users re-use such services is the perceived convenience and their level of satisfaction [5]; on the other hand, Bhattacherjee believes the gap between expectation and experience (namely, confirmation) is another factor influencing the user experience that would induce the re-use of the service [7]. Through the ECM, research can be conducted on each factor that affects the level of satisfaction and the perceived convenience, which in turn induce continued usage [8]. The theoretical ECM is shown in Figure 1 below. The model raises five hypotheses.

- H1: The confirmation of the users exerts a positive influence upon the perceived usefulness of the bikesharing service;

- H2: The users' perceived usefulness of the bike-sharing service exerts a positive influence upon their level of satisfaction;

- H3: The users' perceived usefulness of the bike-sharing service exerts a positive influence upon their continued usage intention;

- H4: The confirmation of the users exerts a positive influence upon their level of satisfaction;

- H5: The level of satisfaction of the users exerts a positive influence upon their continued usage intention. 


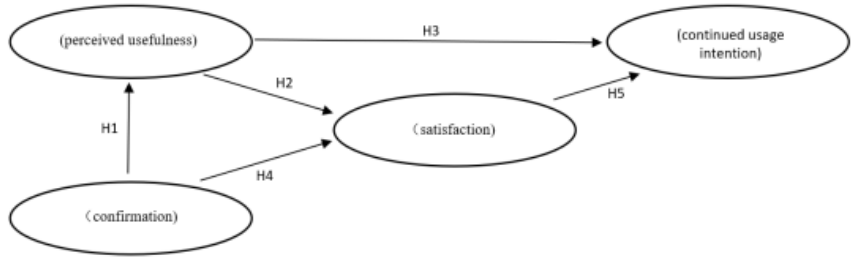

Fig. 1. The continued usage behaviour of the EMC

The ECM is the theory through which researchers study users' continued usage of social websites, instant messaging services, and so on. However, research into regular information technology systems differs from the research on the continued usage of bike-sharing services. The main characteristics of bike-sharing services are convenience and ubiquity. Therefore, in order to produce reliable research, the ECM needs to be extended according to the characteristics of bike-sharing services.

\section{B. The continued usage of bike-sharing services and the ECM}

Emerging during the internet era, shared-bikes bring a brand new experience and enjoyment for people. As a new service, users may be concerned about its safety, not only of the actual riding experience but also of their personal information. The convenience of bike-sharing for shortdistance travel helps users develop an unconscious behavioural tendency in terms of their continued usage. Therefore, this study has added four factors to the ECM: pleasure, trust, habit, and continued usage.

Perceived enjoyment was first used in information technology research, where it has been defined as the level of enjoyment experienced when certain products and services are consumed [10]. One of the expectations of bike-sharing is to get fun and enjoyment from it. Therefore, perceived enjoyment determines the satisfaction of shared-bike users. Additionally, the research of Heijden also shows that the perceived pleasure of the users directly influences the intention of continued usage.

Trust refers to the extent that users can use certain products or services without being concerned. It is a kind of cooperative relationship associating users and businesses. The reason users continue to use certain products is that they believe they are benefiting from this cooperation [11]. A high level of trust can facilitate effective communication between users and businesses, which makes it easier for businesses to pay attention to the users' experience [12]. Therefore, trust positively influences the continued usage of users.

Habit refers to a kind of behavioural dependence developed while users are using certain products or services [13]. When individuals take actions according to their habits, this behaviour relies little on the cognitive resolution for value evaluation and behavioural selection. The more rooted the habit is, the less cognitive resolution there is [14]. Therefore, when certain behaviours become habits, these habits reduce the influence of previously formed cognitive intentions upon the assessment and behavioural choices [15]. In the context of bike-sharing services, once users have developed the habit to use shared-bikes, their continued usage of bike-sharing services is no longer a result of decisions made according to cognitive reasoning. Instead, it is purely an unconscious behaviour, weakening the interconnection between continued usage intention and behaviour.

Continued usage behaviour refers to a behaviour of certain continued usage under the influence of intention of continued usage [16]. It comprises intentional behaviour and habitual behaviour. Continued usage intention can be used to analyse behaviour that is intentional; certain habitual user behaviour can be analysed as well [17].

To sum up, the ECM needs to be extended, as shown in Figure 2 below, which raises the following additional hypotheses:

- H6: The perceived enjoyment of the users has a positive influence on their satisfaction;

- H7: The perceived enjoyment of the users has a positive influence on their continued usage intention;

- H8: The trust of the users has a positive influence on their continued usage intention;

- H9: The continued usage intention of the users has a positive influence on their continued usage behaviour;

- H10: The habits of the users adjust the relationship between their continued usage intention and their continued usage behaviour.

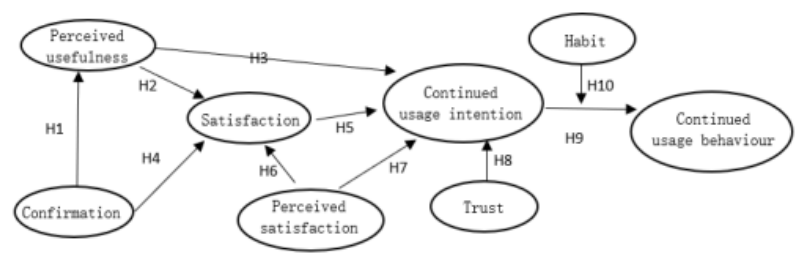

Fig. 2. Continued usage behaviour in the extended EMC

\section{DESIGN OF THE QUESTIONNAIRE AND DATA COLLECTION}

\section{A. Variable measurement and the design of the questionnaire}

This study referred to relevant research in China and other countries for the selection of variables. Once the variables were selected, the questionnaire was designed. Firstly, 30 university students were randomly selected for the primary survey. The questionnaire was modified according to the results of this survey. The Likert scale was used, and each question has five different answers. Each variable confirms detailed survey questions and their origins as shown in Table I. 
TABLE I. THE SPECIFIC QUESTIONS FOR ASSESSMENT AND THEIR REFERENCES

\begin{tabular}{|c|c|c|}
\hline Variable & Choice & Reference \\
\hline Perceived Usefulness(PU) & $\begin{array}{l}\text { PU1: I feel it is easy to find a shared-bike I want. } \\
\text { PU2: I feel I can reach my destination sooner with shared-bikes. } \\
\text { PU3: Shared-bikes can improve my life and productivity. } \\
\text { PU4: In general, bike-sharing is very convenient for me. }\end{array}$ & [5][8] \\
\hline Confirmation(C) & $\begin{array}{l}\text { C1: The user experience of shared-bikes is better than I expected. } \\
\text { C2: The quality of service of bike-sharing is higher than I expected. } \\
\text { C3: In general, bike-sharing service meets my needs. }\end{array}$ & [9] \\
\hline Perceived enjoyment(PE) & $\begin{array}{c}\text { PE1: Bike-sharing can give my life joy. } \\
\text { PE2: The experience of using shared-bikes is pleasant. } \\
\text { PE3: Participating in bike-sharing service related activities makes me happy. }\end{array}$ & [10] \\
\hline Satisfaction(S) & $\begin{array}{l}\text { S1: I am satisfied with the bike-sharing service I had. } \\
\text { S2: I think it is a wise choice for me to use a bike-sharing service. } \\
\text { S3: In general, it is convenient to use shared-bikes. }\end{array}$ & [5][8] \\
\hline Trust(T) & $\begin{array}{l}\text { T1: I feel I can use shared-bikes with no concern. } \\
\text { T2: The platform of bike-sharing service is trustworthy. } \\
\text { T3: The payment of bike-sharing is very reliable. } \\
\text { T4: I feel bike-sharing companies would pay attention to the interests of their users. }\end{array}$ & [11][12] \\
\hline Continued usage intention(CI) & $\begin{array}{l}\text { CI1: I intend to continue using shared-bikes. } \\
\text { CI2: For the rest of my life, I would use shared-bikes. } \\
\text { CI3: If I could go back in time, I would use shared-bikes again. }\end{array}$ & [7] \\
\hline Habit(HAB) & $\begin{array}{l}\text { HAB1: Using a bike-sharing service platform is something that happens without deliberate organisation. } \\
\text { HAB2: When I want to go out, I naturally opt for shared-bikes. } \\
\text { HAB3: I am used to travelling with shared-bikes. }\end{array}$ & [13][144][15] \\
\hline Continued Usage (CU) & $\begin{array}{l}\text { CU1: In the future, I will continue to use shared-bikes. } \\
\text { CU2: In the future, I will use shared-bikes as often or even more often as I have done. } \\
\text { CU3: I am willing to recommend bike-sharing services to my friends and relatives. }\end{array}$ & {$[16][17]$} \\
\hline
\end{tabular}

\section{B. Data collection}

This study obtained data mainly through an online questionnaire ("Wenjuanxing"), but data were also collected by handing out questionnaires in person. Two hundred and seventy-three online questionnaires were collected and 100 were collected in person. Certain questionnaires were excluded, such as those from people who had not used a bike-sharing service (48) and ones that did not provide usable answered. In total, there were 303 valid questionnaires, and the key information about these participants is shown in Table II.

TABLE II. INFORMATION ABOUT THE QUESTIONNAIRE PARTICIPANTS

\begin{tabular}{|c|c|c|c|}
\hline \multicolumn{1}{|c|}{ Category } & Answer & Frequency & Percentage \% \\
\hline \multirow{2}{*}{ Gender } & Male & 120 & 39.6 \\
\cline { 2 - 4 } & Female & 183 & 60.4 \\
\hline \multirow{2}{*}{ Age } & $18-25$ & 281 & 92.74 \\
\cline { 2 - 4 } & $26-35$ & 18 & 5.94 \\
\cline { 2 - 4 } & $\begin{array}{c}\text { Above } \\
35\end{array}$ & 4 & 1.32 \\
\hline \multirow{2}{*}{$\begin{array}{c}\text { Have or never have used bike- } \\
\text { sharing service }\end{array}$} & 1 & 303 & 86.3 \\
\cline { 2 - 4 } & 0 & 48 & 13.7 \\
\hline \multirow{3}{*}{$\begin{array}{c}\text { Monthly income } \\
\end{array}$} & 0 & 209 & 68.98 \\
\cline { 2 - 4 } & $>3000$ & 73 & 24.09 \\
\cline { 2 - 4 } & & 21 & 6.93 \\
\hline
\end{tabular}

\section{EMPIRICAL TEST AND ANALYSIS OF RESULTS}

\section{A. Reliability and validity of the questionnaire}

The reliability includes internal part and external part. The article uses its internal consistency to conduct tests, and the value of Cronbach's $\alpha$ is used to measure the final result. The validity analysis not only analyses convergence validity, but it also analyses discriminant validity. Convergence validity is mainly used to measure the indexes of the theory. The differentiation of the validity refers to the questions being logical. Firstly, factor analysis was performed with the IBM SPSS ${ }^{\circledR}$ software, and the KMO value was calculated. The KMO value and external factors are positively correlated. In this study, $\mathrm{KMO}=0.922$, and the Bartlett test is significant and different from 0 , indicating that this model conforms to the requirements of factor analysis. Based on Table III, the values of Cronbach's $\alpha$ in this study are all equal to or above 0.7 , indicating that the reliability of each question meets the basic requirement. The reliability of the variables in this study are all above 0.7, and the square value of Average Variance Extracted (AVE) value is also higher than 0.5 , indicating a relatively high validity of the research. Comparing the square value of AVE and its corresponding index, the discriminant validity of the scale can be measured. As shown in Table IV below, the square values of the factor AVE (the bold numbers) are all bigger than the indexes of the factors, indicating that the discrimination validity of this scale is relatively better. 
TABLE III. RELIABILITY AND CONVERGENCE VALIDITY

\begin{tabular}{|c|c|c|}
\hline Variable & $\begin{array}{c}\text { Cronbach's } \\
\boldsymbol{\alpha}\end{array}$ & $\begin{array}{c}\text { Combination } \\
\text { reliability }\end{array}$ \\
\hline Perceived usefulness (PU) & 0.782 & 12.288 \\
\hline Confirmation (C) & 0.780 & 12.288 \\
\hline Perceived enjoyment (PE) & 0.858 & 12.288 \\
\hline Satisfaction (S) & 0.707 & 12.317 \\
\hline Trust (T) & 0.851 & 12.288 \\
\hline Continued usage intention (CI) & 0.840 & 12.248 \\
\hline Habit (HAB) & 0.848 & 10.955 \\
\hline $\begin{array}{c}\text { Continued usage behaviour } \\
\text { (CU) }\end{array}$ & 0.838 & 10.956 \\
\hline \multicolumn{2}{|c|}{} \\
\hline
\end{tabular}

TABLE IV. THE SQUARE VALUE OF AVE AND THE INTER-FACTOR CORRESPONDENCE COEFFICIENT MATRIX

\begin{tabular}{|c|c|c|c|c|c|c|c|c|}
\hline Factor & PU & $\mathbf{C}$ & PE & S & T & CI & HAB & CU \\
\hline PU & $\mathbf{0 . 7 8 4}$ & & & & & & & \\
\hline C & 0.651 & $\mathbf{0 . 8 3 2}$ & & & & & & \\
\hline PE & 0.566 & 0.747 & $\mathbf{0 . 7 8 7}$ & & & & & \\
\hline S & 0.618 & 0.730 & 0.598 & $\mathbf{0 . 8 4 3}$ & & & & \\
\hline T & 0.528 & 0.534 & 0.542 & 0.635 & $\mathbf{0 . 7 7 8}$ & & & \\
\hline CI & 0.620 & 0.585 & 0.557 & 0.687 & 0.630 & $\mathbf{0 . 8 4 7}$ & & \\
\hline HAB & 0.597 & 0.631 & 0.607 & 0.642 & 0.646 & 0.769 & $\mathbf{0 . 7 7 3}$ & \\
\hline CU & 0.530 & 0.533 & 0.519 & 0.558 & 0.561 & 0.644 & 0.700 & $\mathbf{0 . 8 6 2}$ \\
\hline
\end{tabular}

\section{B. Model fitting and hypothetical test}

1) Structural model analysis: Structural equation modeling is a recent analytical methodology and is now the main approach to analysing multivariate data. It serves to test target research models and hypothetical overall fit. It is a combination of different types of analytical methodologies, and different models can be formulated, estimated, and tested [18]. Analyses using structural equation models can not only analyse perceived enjoyment, trust, and so on, but they can also substitute other analytical methods. In this study, the target model was analysed with structural equation modeling in the Amos software. The model fit test results are shown in Table $\mathrm{V}$ below. The data show that this target research model conforms to the standard fit indicator. More specifically, the researched shared-bike user continued usage behaviour is compatible. With the routine index between each variable and the $\mathrm{P}$ value, the causal path can be evaluated. If the $\mathrm{P}$ value is smaller than 0.05 , the hypothesis is valid; if the $P$ value is higher than 0.05 , the hypothesis is invalid. Path analysis and test results are shown in Table VI below.

TABLE V. MODEL FITNESS INDEX EVALUATION FORM

\begin{tabular}{|c|c|c|}
\hline Index & $\begin{array}{c}\text { Evaluation } \\
\text { standard }\end{array}$ & Model Value \\
\hline $\begin{array}{c}\text { Chi-square and degree of freedom } \\
\left.\text { ratio ( } \mathrm{x}^{2} / \mathrm{df}\right)\end{array}$ & $<3$ & $9.327 / 8=1.166$ \\
\hline Adaptability index (GFI) & $>0.90$ & 0.992 \\
\hline Adjusted adaptability index (AGFI) & $>0.90$ & 0.966 \\
\hline Standard adaptation index (NFI) & $>0.90$ & 0.994 \\
\hline $\begin{array}{c}\text { Comparative adaptation index } \\
\text { (CFI) }\end{array}$ & $>0.95$ & 0.999 \\
\hline Non-standard fit index (TLI) & $>0.95$ & 0.997 \\
\hline Residual root mean square (RMR) & $<0.05$ & 0.046 \\
\hline
\end{tabular}

TABLE VI. PATH ANALYSIS AND HYPOTHESIS TEST RESULTS

\begin{tabular}{|c|c|c|c|c|c|}
\hline Hypothesis & $\begin{array}{c}\text { Causal } \\
\text { Path }\end{array}$ & $\begin{array}{c}\text { Expectation } \\
\text { symbol }\end{array}$ & $\begin{array}{c}\text { Path } \\
\text { index }\end{array}$ & $\begin{array}{c}\text { P } \\
\text { Value }\end{array}$ & Conclusion \\
\hline $\mathrm{H} 1$ & $\mathrm{C} \rightarrow \mathrm{PU}$ & + & 0.847 & $* * *$ & Valid \\
\hline $\mathrm{H} 2$ & $\mathrm{PU} \rightarrow \mathrm{S}$ & + & 0.167 & $* * *$ & Valid \\
\hline $\mathrm{H} 3$ & $\mathrm{PU} \rightarrow \mathrm{CI}$ & + & 0.173 & $* * *$ & Valid \\
\hline $\mathrm{H} 4$ & $\mathrm{C} \rightarrow \mathrm{S}$ & + & 0.510 & $* * *$ & Valid \\
\hline $\mathrm{H} 5$ & $\mathrm{~S} \rightarrow \mathrm{CI}$ & + & 0.357 & $* * *$ & Valid \\
\hline $\mathrm{H} 6$ & $\mathrm{PE} \rightarrow \mathrm{S}$ & + & 0.067 & 0.157 & Invalid \\
\hline $\mathrm{H} 7$ & $\mathrm{PE} \rightarrow \mathrm{CI}$ & + & 0.142 & $* * *$ & Valid \\
\hline $\mathrm{H} 8$ & $\mathrm{~T} \rightarrow \mathrm{CI}$ & + & 0.195 & $* * *$ & Valid \\
\hline $\mathrm{H} 9$ & $\mathrm{CI} \rightarrow \mathrm{CU}$ & + & 0.655 & $* * *$ & Valid \\
\hline
\end{tabular}

According to the test results, all the hypotheses 234578 are supported except H6. The confirmation has a significant influence upon the perceived usefulness of the service, which proves $\mathrm{H} 1$; perceived usefulness and confirmation have a significant influence upon satisfaction, which proves $\mathrm{H} 2$ and $\mathrm{H} 4$; perceived usefulness, user satisfaction, and trust have a positive influence upon the continued usage intention of the users, proving H9. However, perceived enjoyment was not significantly influenced by user satisfaction, which leaves H6 unproved.

2) Regulation effect analysis: The Amos software was used to determine if habit affects the relationship between the continued usage intention and the behaviour of shared-bike users, and the results are shown in Tables VII and VIII. The figures show that (1) before adding habit, the path index of the continued usage intention and behaviour of shared-bike users was 0.747 , and after adding habit, the path index was 0.528 ; and (2) the interaction term of habit and continued usage intention of bike-sharing services is proportional to the continued usage behaviour of bike-sharing services, and its path index is 0.324 . This indicates that the continued usage intention of bike-sharing services is proportional to its corresponding behaviour. The habit of shared-bike users affects their continued usage intention and behaviour.

TABLE VII. BEFORE ADDING HABIT

\begin{tabular}{|c|c|c|c|}
\hline Casual Path & Path Index & P Value & Result \\
\hline $\mathrm{CI} \rightarrow \mathrm{CU}$ & 0.747 & $* * *$ & Supportive \\
\hline
\end{tabular}

TABLE VIII. AFTER ADDING HABIT

\begin{tabular}{|c|c|c|c|}
\hline Causal Path & Path Index & P Value & Result \\
\hline $\mathrm{CI} \rightarrow \mathrm{CU}$ & 0.528 & $* * *$ & Supportive \\
\hline $\mathrm{HAB} * \mathrm{CI} \rightarrow \mathrm{CU}$ & 0.324 & $* * *$ & Supportive \\
\hline
\end{tabular}

3) Analysis of results and discussion: Firstly, this model has relatively better compatibility according to its path index and $\mathrm{P}$ value. Additionally, all but one of the hypotheses mentioned in this article are valid and meaningful. The perceived usefulness, satisfaction, perceived enjoyment, and trust of shared-bike users are decisive when it comes to continued usage intention. The maximum value of the path index for the satisfaction and continued usage intention of the users is 0.357 , and it is significant at the level of 0.001 . This indicates that the satisfaction of users exerts a significant influence upon their continued usage intention. This conclusion 
conforms to the statement in the ECM that satisfaction drives continued usage intention.

Secondly, this study found that confirmation and perceived usefulness exert a significant influence on the satisfaction of the users. The maximum value of the path index of the experience gap is 0.510 , and it is significant at the level of 0.001 , which indicates that the key factor that affects the satisfaction of shared-bike users is their experience gap. This conforms to statements in the ECM that show that confirmation is the main factor that affects satisfaction. This study also found that perceived enjoyment does not affect the satisfaction of the users significantly. Perceived enjoyment may be affected by perceived usefulness and confirmation. This is because the pleasure of the users would diminish if the perceived usefulness and the level of confirmation were reduced; for example, if the users report issues such as "It is hard to find shared-bikes", "It does not make my life easier", and "The quality of the service is poor compared to what I expected". This, in turn, brings about low perceived enjoyment, which is why perceived enjoyment does not significantly affect the satisfaction of the users.

Thirdly, when the $\mathrm{P}$ value is below 0.001, the trust of shared-bike users in the bike-sharing service exerts a significant influence upon their continued usage. In terms of the use of the shared-bikes, the trust of the users in the platform affects the continued usage of the users to a great extent. The trust of users is reflected in the attention paid by the platforms to the interest of the users. The bike-sharing market attempts to win the trust of the users by providing better services. This is exactly what many enterprises have been doing in recent years. The effect of trust is magnified to a certain extent.

Fourthly, the continued usage intention and behaviour of the users are different, but habit serves to adjust the balance of the two. As market competition increases, many enterprises take advantage of users' habit of using shared-bikes in order to keep their customers, making the use of bike-sharing service commonplace.

This study has raised several suggestions for bike-sharing service providers:

a) Shared-bike companies pay more attention to the experience gap than they do to other factors, which affects the satisfaction of the users. This requires bike-sharing service providers to be user-oriented, which means they have to care about user experience and improve the quality of their service. In turn, the experience gap can be improved along with the continued usage intention.

b) Because satisfaction is one of the most critical factors affecting continued usage, bike-sharing service providers are supposed to use different marketing strategies to keep their old customers than they use to attract new users. Useful functions should be repeatedly made known to new users, while how to use the bike-sharing service effectively should be made known to current users in order to maximise confirmation and satisfaction.

c) In order to win the trust of the users, bike-sharing service providers have to spend more time communicating with their users when they optimise their platform, which will boost the trust the users have in them.

d) How to retain shared-bike users is also important. If users develop a reliance upon the bike-sharing service, riding shared-bikes becomes their habit. Companies can encourage users to continue to use bike-sharing services, increase their frequency of riding shared-bikes, and develop their habit of using shared-bikes by issuing coupons, riding stickers, and other promotions.

Companies can also establish a credit accumulation system through which the reasonable use of the bike-sharing service can be rewarded. The credits they receive in the system can be redeemed into days when they can use the bikes free of charge. The continued usage intention of the users can be improved to a certain extent through a discount system.

\section{CONCLUSION}

Taking bike-sharing services as its research object, this study analyzed the continued usage behaviour of shared-bike users by introducing an extended ECM based on the characteristics of bike-sharing services. The methodology of structural equation modeling was used to examine the hypotheses. The results indicate that the extended ECM can effectively explain the continued usage behaviour of sharedbike users. Several suggestions were provided regarding how bike-sharing service providers can improve the continued usage intention and behaviour of their users.

This research has achieved certain goals, but various aspects need to be improved to overcome restrictive conditions. Firstly, the target age group of this research was 18- to 25-yearolds, mostly university students. Further research should include more age groups in order to assure the randomness of the sample selection. Secondly, this study selected eight factors influencing the continued usage of shared-bike users in general, but the factors affecting the continued usage of users are very complicated. Further research should include more variables to complete the model. Moreover, the process of conducting the survey and questionnaire of users from different regions, of different genders, from different age groups, and with different levels of income could be improved.

Funding: This research was funded by the Research Center for Fiscal and Financial Development in HaiXi, grant number XTZX1816.

Conflicts of Interest: The authors declare no conflict of interest.

\section{Appendix}

Questionnaire: Research on the continued usage behaviour of shared-bike users

1. Your gender is: [Multiple choice question] [Compulsory]

$\circ$ Male $\circ$ Female

2. Your age is: [Multiple choice question] [Compulsory]

- 18-25 ○ 26-35 ○ 36 or above

3. Have you ever used shared-bikes: [Multiple choice question] [Compulsory]

$\circ$ Yes ○ No 
4. Your monthly income is: [Multiple choice question] [Compulsory]

$\circ 0 \circ 0-3000 \circ$ above 3000

5. Please choose the most appropriate answer according to your actual conditions: [Matrix Scale Questions] [compulsory]

\begin{tabular}{|l|c|c|c|c|c|}
\hline & $\begin{array}{c}\text { Totally } \\
\text { disagree }\end{array}$ & Disagree & $\begin{array}{c}\text { Agree } \\
\text { to some } \\
\text { extent }\end{array}$ & Agree & $\begin{array}{c}\text { Totally } \\
\text { agree }\end{array}$ \\
\hline $\begin{array}{l}\text { PU1: I think it is very } \\
\text { easy to find the } \\
\text { shared-bikes I like. }\end{array}$ & $\circ$ & $\circ$ & $\circ$ & $\circ$ & $\circ$ \\
\hline $\begin{array}{l}\text { PU2: I think shared- } \\
\text { bikes can help me get } \\
\text { to my destination } \\
\text { faster. }\end{array}$ & $\circ$ & $\circ$ & $\circ$ & $\circ$ & $\circ$ \\
\hline $\begin{array}{l}\text { PU3: Bike-sharing } \\
\text { services can improve } \\
\text { my life and my } \\
\text { productivity. }\end{array}$ & $\circ$ & $\circ$ & $\circ$ & $\circ$ & $\circ$ \\
\hline $\begin{array}{l}\text { PU4: In general, } \\
\text { bike-sharing services } \\
\text { are useful to me. }\end{array}$ & $\circ$ & $\circ$ & $\circ$ & $\circ$ & $\circ$ \\
\hline
\end{tabular}

6. Please choose the most appropriate answer according to your actual conditions: [Matrix Scale Questions] [compulsory]

\begin{tabular}{|l|c|c|c|c|c|}
\hline & $\begin{array}{c}\text { Totally } \\
\text { disagree }\end{array}$ & Disagree & $\begin{array}{c}\text { Agree } \\
\text { to some } \\
\text { extent }\end{array}$ & Agree & $\begin{array}{c}\text { Totally } \\
\text { agree }\end{array}$ \\
\hline $\begin{array}{l}\text { C1: My bike-sharing } \\
\text { experience exceeds } \\
\text { my expectation. }\end{array}$ & $\circ$ & $\circ$ & $\circ$ & $\circ$ & $\circ$ \\
\hline $\begin{array}{l}\text { C2: The quality of } \\
\text { the service of bike- } \\
\text { sharing exceeds my } \\
\text { expectation. }\end{array}$ & $\circ$ & $\circ$ & $\circ$ & $\circ$ & $\circ$ \\
\hline $\begin{array}{l}\text { C3: In general, } \\
\text { shared-bikes satisfy } \\
\text { my needs. }\end{array}$ & $\circ$ & $\circ$ & $\circ$ & $\circ$ & $\circ$ \\
\hline
\end{tabular}

7. Please choose the most appropriate answer according to your actual conditions: [Matrix Scale Questions] [compulsory]

\begin{tabular}{|l|c|c|c|c|c|}
\hline & $\begin{array}{c}\text { Totally } \\
\text { disagree }\end{array}$ & Disagree & $\begin{array}{c}\text { Agree } \\
\text { to some } \\
\text { extent }\end{array}$ & Agree & $\begin{array}{c}\text { Totally } \\
\text { agree }\end{array}$ \\
\hline $\begin{array}{l}\text { PE1: Bike-sharing } \\
\text { services bring } \\
\text { enjoyment to my life. }\end{array}$ & $\circ$ & $\circ$ & $\circ$ & $\circ$ & $\circ$ \\
\hline $\begin{array}{l}\text { PE2: The experience } \\
\text { of using shared-bikes } \\
\text { is pleasant. }\end{array}$ & $\circ$ & $\circ$ & $\circ$ & $\circ$ & $\circ$ \\
\hline $\begin{array}{l}\text { PE3: Participating in } \\
\text { activities relating to } \\
\text { shared-bikes makes } \\
\text { me happy. }\end{array}$ & $\circ$ & $\circ$ & $\circ$ & $\circ$ & $\circ$ \\
\hline
\end{tabular}

8. Please choose the most appropriate answer according to your actual conditions: [Matrix Scale Questions] [compulsory]

\begin{tabular}{|l|c|c|c|c|c|}
\hline & $\begin{array}{c}\text { Totally } \\
\text { disagree }\end{array}$ & Disagree & $\begin{array}{c}\text { Agree to } \\
\text { some } \\
\text { extent }\end{array}$ & Agree & $\begin{array}{c}\text { Totally } \\
\text { agree }\end{array}$ \\
\hline $\begin{array}{l}\text { S1: The bike-sharing } \\
\text { service is } \\
\text { satisfactory. }\end{array}$ & 0 & $\circ$ & 0 & 0 & 0 \\
\hline $\begin{array}{l}\text { S2: I think it is a } \\
\text { wise choice to use } \\
\text { shared-bikes. }\end{array}$ & 0 & $\circ$ & $\circ$ & 0 & $\circ$ \\
\hline $\begin{array}{l}\text { S3: In general, the } \\
\text { user experience of } \\
\text { bike-sharing is } \\
\text { smooth. }\end{array}$ & $\circ$ & $\circ$ & $\circ$ & 0 & $\circ$ \\
\hline
\end{tabular}

9. Please choose the most appropriate answer according to your actual conditions: [Matrix Scale Questions] [compulsory]

\begin{tabular}{|l|c|c|c|c|c|}
\hline & $\begin{array}{c}\text { Totally } \\
\text { disagree }\end{array}$ & Disagree & $\begin{array}{c}\text { Agree } \\
\text { to some } \\
\text { extent }\end{array}$ & Agree & $\begin{array}{c}\text { Totally } \\
\text { agree }\end{array}$ \\
\hline $\begin{array}{l}\text { T1: I feel safe when I } \\
\text { use shared-bikes. }\end{array}$ & 0 & 0 & 0 & 0 & 0 \\
\hline $\begin{array}{l}\text { T2: The bike-sharing } \\
\text { platform is } \\
\text { trustworthy. }\end{array}$ & $\circ$ & $\circ$ & $\circ$ & 0 & 0 \\
\hline $\begin{array}{l}\text { T3: The payment for } \\
\text { bike-sharing is } \\
\text { concern-free. }\end{array}$ & $\circ$ & 0 & 0 & 0 & 0 \\
\hline $\begin{array}{l}\text { T4: I think bike- } \\
\text { sharing service } \\
\text { companies pay } \\
\text { attention to the } \\
\text { interests of the users. }\end{array}$ & $\circ$ & $\circ$ & $\circ$ & 0 & $\circ$ \\
\hline
\end{tabular}

10. Please choose the most appropriate answer according to your actual conditions: [Matrix Scale Questions] [compulsory]

\begin{tabular}{|l|c|c|c|c|c|}
\hline & $\begin{array}{c}\text { Totally } \\
\text { disagree }\end{array}$ & Disagree & $\begin{array}{c}\text { Agree to } \\
\text { some } \\
\text { extent }\end{array}$ & Agree & $\begin{array}{c}\text { Totally } \\
\text { agree }\end{array}$ \\
\hline $\begin{array}{l}\text { CI1: I plan to } \\
\text { continue to ride } \\
\text { shared-bikes. }\end{array}$ & $\circ$ & $\circ$ & $\circ$ & $\circ$ & $\circ$ \\
\hline $\begin{array}{l}\text { CI2: I will keep } \\
\text { using bike-sharing } \\
\text { services for the rest } \\
\text { of my life. }\end{array}$ & $\circ$ & $\circ$ & $\circ$ & $\circ$ & $\circ$ \\
\hline $\begin{array}{l}\text { CI3: If I could go } \\
\text { back in time, I } \\
\text { would still choose to } \\
\text { use shared-bikes. }\end{array}$ & $\circ$ & $\circ$ & $\circ$ & $\circ$ & $\circ$ \\
\hline
\end{tabular}

11. Please choose the most appropriate answer according to your actual conditions: [Matrix Scale Questions] [compulsory]

\begin{tabular}{|l|c|c|c|c|c|}
\hline & $\begin{array}{c}\text { Totally } \\
\text { disagree }\end{array}$ & Disagree & $\begin{array}{c}\text { Agree to } \\
\text { some } \\
\text { extent }\end{array}$ & Agree & $\begin{array}{c}\text { Totally } \\
\text { agree }\end{array}$ \\
\hline $\begin{array}{l}\text { HAB1: Using the } \\
\text { bike-sharing service } \\
\text { platform is very } \\
\text { natural. }\end{array}$ & $\circ$ & $\circ$ & $\circ$ & $\circ$ & $\circ$ \\
\hline $\begin{array}{l}\text { HAB2: When I feel } \\
\text { like going out, using } \\
\text { a bike-sharing } \\
\text { service is a must. }\end{array}$ & $\circ$ & $\circ$ & $\circ$ & $\circ$ & $\circ$ \\
\hline $\begin{array}{l}\text { HAB3: I am used to } \\
\text { riding shared-bikes. }\end{array}$ & $\circ$ & $\circ$ & $\circ$ & $\circ$ & $\circ$ \\
\hline
\end{tabular}

12. Please choose the most appropriate answer according to your actual conditions: [Matrix Scale Questions] [compulsory]

\begin{tabular}{|l|c|c|c|c|c|}
\hline & $\begin{array}{c}\text { Totally } \\
\text { disagree }\end{array}$ & Disagree & $\begin{array}{c}\text { Agree } \\
\text { to some } \\
\text { extent }\end{array}$ & Agree & $\begin{array}{c}\text { Totally } \\
\text { agree }\end{array}$ \\
\hline $\begin{array}{l}\text { CU1: In the future, I } \\
\text { will keep using bike- } \\
\text { sharing services. }\end{array}$ & $\circ$ & 0 & $\circ$ & $\circ$ & 0 \\
\hline $\begin{array}{l}\text { CU2: In the future, I } \\
\text { will use shared-bikes } \\
\text { as often or more often } \\
\text { as I have done. }\end{array}$ & $\circ$ & 0 & $\circ$ & $\circ$ & $\circ$ \\
\hline $\begin{array}{l}\text { CU3: In the future, I } \\
\text { will recommend bike- } \\
\text { sharing services to } \\
\text { my friends and } \\
\text { relatives. }\end{array}$ & $\circ$ & $\circ$ & $\circ$ & $\circ$ & 0 \\
\hline
\end{tabular}




\section{REFERENCES}

[1] Xuan Zhang; QInglie Wu. Mobile E-Commerce Based on Extended ECM Continues to Use Intentional Research. Journal of Taiyuan University of Technology, 2010, 41(01): 28-32.

[2] Wenjing Ge. Discussion on the development of shared bicycle and its profit path. Modern Commerce, 2017,(14): 37-39.

[3] Yehu Di; Tianxin Liu. Legal issues of shared bicycle rental. Journal of Yangzhou University, 2017, 21(04): 39-46.

[4] Mengyuan Wang. Discussion on the Legal Responsibility of Destroying Shared Bicycle Behavior. Journal of Wuhan Vocational College of Transportation, 2017, 19(02): 9-14.

[5] Oliver R L. A Cognitive Model of the Antecedents and Consequences of Satisfaction Decisions. Journal of Marketing Research, 1980, 17(4): 460-469.

[6] Davis F D. A Technology Acceptance Model for Empirically Testing New End-User Information Systems: Theory and Results. PhD.Massachusetts Institute of Technology, Massachusetts,1986.

[7] Bhattacherjee A. Understanding Information Systems Continuance: An Expectation Confirmation Model. MIS Quarterly, 2001, 25(3): 351-370.

[8] Yuan Shunbo, Liu Yong, Yao Ruihong, Liu Jing. An Investigation of Users' Continuance Intention towards Mobile Banking in China. Information Development, 2014, 32(1): 20-34.

[9] Kotler P. Marketing management: The millennium edition. Upper Saddle River: Prentice Hal, 2000, 132-142.

[10] Carroll J M, Thomas J C. Fun. SIGCHI Bulletin, 1988, 19(3): 21-24.
[11] Mital; M Israel D.; Agarwal S. Information Exchange and Information Disclosure in Social Networking Website: Mediating Role of Trust. Learning Organization, 2010, 17 (6): 479-490.

[12] Mayer R C.; Davis J H.; Schoorman F D. An Integration Model of Organizational Trust. The Academy of Management Journal, 1995, 20(3): 709-734.

[13] Hong Liu.; Lei Pei.; Jianjun, Sun. Empirical analysis of the continued use of video website users based on the expected confirmation model. Library and intelligence, 2014,(3): 94-103.

[14] De Guinea A O.; Markus M L. Why Break the Habit of a Lifetime? Rethinking the Roles of Intention, Habit, and Emotion in Continuing Information Technology Use. MIS Quarterly, 2009, 33(3): 433-444.

[15] Aarts H.; Dijksterbuis A. Habits as knowledge structures: automaticity in goal-directed behaviour. Journal of Personality and Social Psychology, 2000, 78(1): 53-63.

[16] Xuchuan Lin. Bolted Built-Up Columns Constructed of High-Strength Steel under Combined Flexure and Compression. Journal of Structural Engineering, 2016, 2, 15-23.

[17] Yang H.; Gui S. Factors Influence academic library user's intention to use mobile systems: A comparison of current users and potential adopters. Chinese Journal of Library and Information science, 2014, 7(3): 64-80.

[18] Rahmadi R.; Groot P.; Heins M.; Knoop H.; Heskes T. Causality on cross-sectional data: Stable specification search in constrained structural equation modeling. Applied Soft Computing, 2016, 52: 687-698. 